\title{
The Role of Women in Selected Batak Toba Songs Based On Gender Equality
}

\author{
Martina Girsang ${ }^{1}$, IkhwanuddinNasution ${ }^{2}$, Asmyta Surbakti ${ }^{3}$ \\ ${ }^{1}$ North Sumatera University, Medan, Indonesia \\ ${ }^{2}$ North Sumatera University, Medan, Indonesia \\ ${ }^{3}$ North Sumatera University, Medan, Indonesia
}

\begin{abstract}
The purpose of the study is to interpret the role of women according to both the children and the women in some selected Batak Toba songs, HNDI, AHDHDA, based on the gender equality. The role of women is a hot issue in both national and international communities for it gives a big influence in both domestic and public work. The researcher of the study takes the selected songs as her main source of data, and the second ones are from books and internet.The method of the research is qualitative one for she uses interpreting, describing relating to the extrinsic approach. In gathering the data she finds some CD Cassettes and browsing from the internet which is related to the topic, select them, listen them many times till she is sure enough finding the correct songs, then analyze them relate to the gender equality theory.
\end{abstract}

Keywords: The Role of Women, Selected Batak Toba Songs, Gender Equality.

\section{Introduction}

Talking about the role of women should be related to the activities and the responsibilities of the women both in domestic and public jobs. In this study the role of the women which will be discussed is the role of the women according to both the Batak Toba children and women that will be found in the selected Batak Toba songs, Holong $\mathrm{Ni}$ Da Inang (HNDI) created by FirmanManurung (FM) and AnakHonhi Do Hamoraon Di Au (AHDHDA) created by Nahum Situmorang (NS) based o the gender equality.

Recently it is often issued about the gender equality in the society, both in the national and international ones .It can be seen by the presence of the women in some events and field of job as the implementation of the role of the women. But most of them working in both the domestic and public not because they want to imply the role of the women as well, but for they want to survive their family living only or be a bread winner. Some say that as a woman, her role is as a house keeper who works as a domestic worker and manages and takes care of all her family member. A man must work in public for earning money. But in practice most of the women play the role of men and women work both as the domestic and public worker for the money their husband earned is not enough for the family expense or the man has no permanent work or job, even for the women been a widow. So the women do not assist their husband only but they are being the main actor or the bread winner as well.

So what is Gender Equality? There are some opinions about this, there is one says the gender equality is only an opposition of the different behavior toward the women; there is also says the gender equality is an understanding of the unfair behavior toward the women; and other says the gender equality is an autonomy behavior in doing anything or in deciding the way of life. According to Hubeis (2010:49) "It is the measurable equal representations of women and men for women and men have role each other, so that men and women should receive an equal treatment.

Indonesia as a big country has 33 provinces which has been rich with differ cultures and languages .But it also has the national language itself ,Indonesia, as the unity among the province communities. One of the province is North Sumatra one which the capital town is Medan. Medan is always identical to Bataknese people. There are five kinds of so-called Batak, such as: the Batak Toba, BatakSimalungun, BatakKaro, BatakMandailing, and Batak Pak-Pak. Among the five Batak tribes the researcher is more interested in observing the Batak Toba for it has some beautiful songs which are related to the topic.

In this study the researcher chose two selected songs that contain of the role of the women according to the children and the women themselves, such as : 1.Holong Ni Da Inang ( HNDI) 'The Love of a Mother' created by FendiManurung (FM); 2. Anakhon Hi Do Hamoraon Di Au (AHDHDA) 'My Children Is My Wealth'created by Nahum Situmorang (NS).

In gathering and completing the data the researcher gets two primary source of data ,such as: One, The selected Batak Toba songs that are connected to the topic of discussion; Two, reading some books which have relationship to the topic, and also browsing from internet. 
In analyzing the data she uses the extrinsic approach, and the study is written by using the qualitative method for it leads her to describe, to interpret, and to analyze.

So by the selected Batak Toba songs the readers or the listeners know the role of the women in BatakToba tribe especially the role according to both of the children and the women that based on the gender equality.

\subsection{The Objective of the Study}

The objectives of the study are to find the role of the women both according to the children and the women themselves in some of the Batak Toba selected songs, HNDI, AHDHDA, and to interpret, to describe them related to hermeneutic, approaches that based on the gender equality

\subsection{The Scope of the Study}

The scope of the Study focuses only on the analysis of: finding the role of women according to the children in the Batak Toba selected songs, HNDI, AHDHDA, and analyze them based on the gender equality.

\subsection{Theoretical Approach}

According to Rene Welleck and Austin Warren (1977:25) there are two kinds of theoretical approaches in discussing a literary work, such as: Intrinsic and extrinsic approach. Intrinsic approach is the analysis of the text without relating it to the other disciplines of knowledge, either social or political condition. While extrinsic is an approach which is related to the other disciplines, such as: psychology, philosophy, politic, social, history, and etc, Kasim (2003:60-61).

In analyzing the Batak Toba selected songs, HNDI, AHDHDA; the researcher uses extrinsic approach which is related to the hermeneutic theory.. Etymologically Hermeneutics comes from Greece language 'hermeneutic' means to interpret. The literary work, in this study the selected songs, need to be interpreted for the work contain of language, and in the language is also hiding message Ratna (2004: 45)

\subsection{Data Analysis}

\section{Data Analysis And Findings}

The main source of the data, the Batak Toba selected songs, Holong Ni Da Inang HNDI and Anakhon Hi Do Hamoraon Di Au AHDHDA, were focused as the point of the analyzing. The songs were analyzing which are related to the role of the women in Batak Toba communities according to the children and the women, based on the gender equality.

\subsubsection{Holong Ni Da Inang(HNDI) 'The Love Of A Mother' Created By: FendiManurung(FM)} Source Language (SL)

\begin{tabular}{|l|l|}
\hline Toho ma ho inangpangintubunalambokmalilu & 'It is true that you are a gentle mother ' \\
\hline Dihaburjuonmituhamianakmon pa anju-anjuhami & 'You are so kind and care for all of your children' \\
\hline Dang tarsuhatan be da haburjuon mi tuhamigellengmon & 'It cannot be measured your love to your children' \\
\hline Mulaisiannameneksahattunamagodangro di namarhasohotan & $\begin{array}{l}\text { 'You love us all since you born us ,till we are all adult, } \\
\text { even till we've got married' }\end{array}$ \\
\hline Manganju ma ho inangpangintubutuhamianakmon & 'Be patient mom for all of our bad behavior and careless' \\
\hline Dang alanitoisnirohanamI & 'we did not mean it' \\
\hline So namarnasudaholongnirohamituhamigellengmon & 'Please mom do not stop your love for us all' \\
\hline Anggiat ma inangsaidibegeTuhanta & 'Hope God listen to your prayer' \\
\hline Tangiang mi tuhamigellengmon & 'Your pray for us all your children' \\
\hline Asatung lam tudengganna & 'So all our life would be better' \\
\hline Da parngoluan on inangkunaburju & 'My life would be better ,my dear mom' \\
\hline Dang tarhasuhatan be da haburjuan mi tuhamigellengmon & $\begin{array}{l}\text { 'It cannot be measured your love and kindness for all of } \\
\text { us your children' }\end{array}$ \\
\hline Mulaisiannamenek,sahattunamagodangro di namarhasohotan & $\begin{array}{l}\text { 'Since you born us all, tillwe are all adult ,even till we've } \\
\text { got married' }\end{array}$ \\
\hline
\end{tabular}

2.1.2 ANAKHON HI DO HAMORAON DI AU (AHDHDA) 'My Children is My Wealty' Created by Nahum S Situmoran (NS)

Source Language (SL)

Target Language (TL)

\begin{tabular}{|l|l|}
\hline Marhoi-hoi pe au inang da tudoloktutoruan & Though I am tired going around' \\
\hline Mangaluluingolu-ngolunaboiparbodarian & 'Earning money for life' \\
\hline Asal ma sahatgellenghi da saisahattutujuan & 'As far as my children achieve their goal' \\
\hline Anakhon hi do hamoraon di au & 'My children is my wealth' \\
\hline Nang so tarihuthon au peangkadongan & 'though I cannot get along my friends' \\
\hline Ndadapolamarsak au disi & 'I am not sad at all' \\
\hline Alai anakhon hi da ndangjadihatinggalansiandonganmagodangna I & 'But all my children must be better than their friends' \\
\hline Hu hohopemansariariannangbodarilaopasingholahongellenghi & $\begin{array}{l}\text { 'I work hard day and night giving good education for my } \\
\text { children' }\end{array}$ \\
\hline
\end{tabular}


The Role of Women in Selected Batak Toba Songs Based On Gender Equality

\begin{tabular}{|l|l|}
\hline Naikhon do singkolasatimbotimbonasingkapninatolapgogohki & have to give them a good education, as higher as possible' \\
\hline Ai tung so boipe au inang da marsedanmarberlian & 'Though I have no car nor jewelry' \\
\hline Tarsongondongan-dongan hi da nalobihpansarian & 'Like my friends who have a wealth' \\
\hline Alai sudenagellenghi da saisahattutujuan & 'But all my children must achieve their goal' \\
\hline Anakhonhi do hamoraon di au & 'My children is my wealth' \\
\hline
\end{tabular}

1.2 The role of the Women both according to children and the women herself in Batak Toba Selected Songs, HNDI and AHDHDA based on the Gender Equality

\subsubsection{Holong Ni Da Inang (HNDI) 'The Love of a Mother' created by FendiManurung FM) Based on the Gender Equality}

The HNDI is a song talking about the role of women according to the children .Talking about the role of woman it should involve the role and the women, both in domestic and public job as the bread winner. There are some opinions about the role of the women 'as it was mentioned in the previous point. But whatever the opinion is surely a woman has a very important role both in the domestic and the public work, weather as a house keeper, a merchant, a career woman, etc. The role of a woman is a human being remains her most essential role in life. She must confirm in her action that she is a person of reason, will affection, and also a mission to carry out and should prove that she has an ability to take part in life.

Generally Indonesian women are famous as stereotype of a hard worker, especially the Bataknese women. In the Batak Toba tribe the role of women had been practiced long time ago before it was issued hotly in the society. There is an unwritten principle and in the same time as the women's goal of life that they want to form in the reality such as: hamoraon, hagabeon, hasangapon 'Wealth, Generation, Honor' Simanjuntak (2009:159) so that they have to struggle for the children no matter what or how the way is as far as it is still in the positive one or in the right way.

According to the researcher most of the Bataknese women are super women for they could do any kind of job both in domestic and public as the bread winner. The character of the super women is the women who can prepare umbrella before it rains. The women who always make preparation of what she wants to do. This is also the implementation of the role of the women.

There are five kinds that so-called Batak tribe, such as: the Batak Toba, BatakSimalungun, BatakKaro, BatakMandailing, and Batak Pak-Pak. Among them all, the Batak Toba is a tribe which likes most creating and singing songs. The songs contain of many kinds of messages weather it is about sadness, happiness, adore, love, struggle, role of women and other things.

Actually the Bataknese Toba Women know only a bit about the gender equality though they work both in domestic and public job as the bread winner. They will do anything for the sake of their children's education no matter the kind of the job as far as it's in positive one, they will sacrifice their life for their children though they have to work from morning till late at night, or under the sunrise and the rainfall, they will not keep silent only though their husband have no money or lazy to work or have no work or other reasons.

Their children know and can feel about that already, for anytime the children expressing their feeling, wish, adore, thanks, love, etc, they love most expressing it to their mother. Here is the role of the women according to the children that can be seen by the following selected songs:

The lyric of HNDI created by FM is touchable for who those understand. In the first stanza, FM as the writer of HNDI wants to show the listener or the reader how a kid feels and expresses the love, gentle and the responsibility of a mom as the form of her role as a woman and a mother. As a kid he/she realizes he/she will never been able to measure or to pay back his mom's love, affection, and responsibilities by caring, educating, loving him since he was in his mom's womb, childhood, adult, even till he got married. On the other hand for a mother, though her children are bad or good, she is always patience in supporting them and her love will never been finished.

It can be seen by the following lyrics:

"Toho ma ho inang/ inangpangintubunalambokmalilu/

dihaburjuan mi tuhamianakmon pa anju-anjuhami/

dangtarsuhatan be da haburjuan mi tuhamigellengmon/

mulaisiannameneksahattunamagodang

rodinamarhasohotan".

'It is true that you are a gentle mother/

you are so kind and care of all your children/

It cannot be measured your love to your children/

since childhood, adult, even till they married'. 
There is a famous proverb in Indonesian language which says:" The love of children is along the road, but the love of a mother is everlasting and forever". Why? Though her children do not care of her, do not remember her for any kind of reasons but she understand her children. Every minute of her life never forget to pray for them, their health, and their successful and better life. The researcher trusts that a pray gives a big effect toward the children's success.

By the lyric of the HNDI, it can be seen how a mother in Batak Toba tribe love and care her children even till they got married. It shows the reader or the listener that a mother in the tribe has done her responsibility to take her children into a successful, into a better life. It means that though she is a woman, but she is able, strong, patient in taking her children into the successful gate, no matter the way as far as it is still on the right way. But the biggest effect that the children feel and beg their mother does is keep praying for them, such:

"Manganju ma ho inangpangintubutuhamianakmon/

dangalanitoisnami/ saiunangmarnasudaholongnirohamituhamigellengmon/anggiat ma da inangsai di begeTuhan ta tangiang mi tuhami da gellengmon/ asa lam tudenggannaparngoluan on inangkunaburju“.

'Be patient mom for all of our bad behavior and careless/

we do not meant it mom/ please mom, do not stop your love for us all your children/ hope God listen to our pray mom/ your pray for your children mom/ so our life would be better.'

But unluckily, many times in practice people, especially men don't know how to appreciate a woman's deed for they think it's her duty, her responsibility doing the domestic work. The researcher is not sure whether a man can do like the woman does, especially in taking the children into the successful by guiding and giving them good education in formal or in informal one, be patient and strong in facing the children's bad character. And in the same time, the women involving in some activities in the society, such as following the tradition ones, and she has to work in public as the bread winner. These are all the reasons the children can express their feeling, wish, love most to their mother than to their father for they experience and see all their mother's role in their daily life. It can be seen by the followings:

"Toho ma ho inangpangintubunalambokmalilu/ dihaburjuanmituhamianakmonpaanju-anjuhami/ dang tarsuhatan be da haburjuan mi tuhamigellengmon/mulaisiannameneksahattunamagodangro di namarhasohotan/ anggiat ma inangsaidibegeTuhantatangiang mi tuhamigellengmonasa lam denggannaparngoluan on inangkunaburju".

"It is true you are my mother who is kind and gentle for us all your children/ your love for us is unmeasured and uncountable/ you took care of us since our childhood, adult, even till got married/ hope God blessing us all so that we will get a better life, our splendid mother ".

So by the HNDI song created by FM it can be seen the role of the woman according to the children in the Batak Toba community that is related to the gender equality.

\subsubsection{Anakhon Hi Do Hamoraon Di Au (AHDHDA) 'My Children are my Wealthy' Created by Nahum Situmorang (NS)}

The AHDHDA is a very popular song in North Sumatra Province, Indonesia, especially in Batak Toba tribe. The song is sung in much kind of events, sad or happy ones, especially in Batak Toba traditional party. The song is very familiar in the entire circle of the Bataknese communities.

The lyric of the AHDHDA is simple enough, and easy to understand .But its content is full of women's role in the family, whether it is in domestic and public jobs as the bread winner. The women is ready in doing a hard working by earning money for the need of her children, no matter if she does it under the sun rises or by the rain fall either. She is ready being apart with her friends without enjoying fun with them as far as she can give a good education for her children. She is ready to deny herself in buying car, jewelry, for she wants her children get a better and high education. She has an ambition to take her children to the gate of successful as much as possible. For her children is her wealthy who she proud of. It can be seen by the following quotations:

"Marhoi-hoi pe au inang da tudoloktutoruan/ mangaluluingolu-ngolunaboiparbodarian/ asal ma sahatgelleng hi da saisahattutujuan/ anakhon hi do hamoraon di au/ aitung so boipe au inang da marsedanmarberlian/ tarsongondongan-dongan hi da nalobihpansarian/ alaisudenagellenghi da saisahattutujuan. Anakhonhi do hamoraon di au".

'Though I am tired going around earning money for life it does not matter as far as my children achieve their goal/ my children are my wealt/ though I have neither car nor jewelry like my friends have/ but all my children is not far from the successful for my children is my wealth".

So by the quotation above it can be seen the role, struggle, and the sacrifice of the Batak Toba's woman in taking her children into a successful life. 


\subsection{Findings}

Based on the objectives of the study finding the role of the women according to both the children and the women in the Batak Toba selected songs, HNDI, AHDHA, there are some findings that can be seen, such as: In both the two Batak Toba selected songs, HNDI, AHDHA, can be found the gender equality practice both according to the children and the women. According to the children the role of the women gives a big influence for them by doing the role in domestic and public job as a bread winner. That's why the children express their thanks by adoring, loving, praying their mother for she has done her responsibility to her children as the implementation of the role of women. And in the same time it has the connection to the implementation of the gender equality.

The role of the women in the selected songs, HNDI, AHDHA, according to the women can be seen by doing their responsibility as the bread winner (Actually this is the role of the man). The women show their responsibility for the sake of their children's good education.

\section{Conclusions}

Regarding to the objective of the study by interpreting, describing, and descripting the realistic of the role of the women in the Batak Toba selected songs, HNDI, AHDHDA, the researcher come to the conclusions that :

1. The women in the Batak Toba had implemented their role in both the domestic and public job as bread winner by doing many kinds of jobs, and always place God after them.

2. By interpreting, describing, decrypting the Batak Toba selected songs, HNDI and AHDHDA, the reader known already that the Batak Toba women had implemented and practiced their role weather in domestic or in the public job. And it means that the Batak Toba women had practiced the gender equality long before the gender equality being a hot issue.

\section{References}

[1]. Hubeis, Vitalayala,Aida. (2010). PemberdayaanPerempuandariMasakeMasa. Bogor: PT Penerbit IPB Press Kampus IPB Taman Kencana.

[2]. Kasim, Razali. (2003). Literature and Psychology. Medan: USU press

[3]. Ratna, Kuta, Nyoman. (2004). Yokjakarta: Teori,MetodedanTeknikPenelitianSastra. PustakaPelajarCelebanTimur UH III/548.

[4]. Ratna, Kuta, Nyoman. (2009). Yokyakarta :StilistikaKajianPuitikaBahasa, Sastra, danBudaya. PustakaPelajarcelebanTimur UH III $/ 548$.

[5]. Simanjuntak, Bungaran, Antonius. (2009). Jakarta: Konflik Status danKekuasaan Orang Batak Toba. YayasanObor Indonesia

[6]. Wellek, Rene and Austin Warren. (1977). Theory oh Literature . Third Edition. New York: A Harvest Book, Brace \& World, Inc.

[7]. http://scholarworks.umass.edu/disertation/AA19809402/

[8]. http:// en.wikipedia.org/wiki/Toba.Batak.language.

[9]. http://karaoke batak.blogspot.com/2012/06/daftar-lagu-batak.htm. 